\title{
Polysèmes
}

Revue d'études intertextuelles et intermédiales

\section{Revamping Carmilla: The Neo-Victorian Transmedia Vlog Adaptation}

Les adaptations néo-victoriennes transmédiatiques en vlog : l'exemple de Carmilla

\section{Caroline Duvezin-Caubet}

\section{OpenEdition}

Electronic version

URL: http://journals.openedition.org/polysemes/6926

DOI: $10.4000 /$ polysemes.6926

ISSN: 2496-4212

Publisher

SAIT

Electronic reference

Caroline Duvezin-Caubet, «Revamping Carmilla: The Neo-Victorian Transmedia Vlog Adaptation », Polysèmes [Online], 23 | 2020, Online since 30 June 2020, connection on 02 July 2020. URL : http:// journals.openedition.org/polysemes/6926; DOI : https://doi.org/10.4000/polysemes.6926

This text was automatically generated on 2 July 2020.

Polysèmes 


\title{
Revamping Carmilla: The Neo- Victorian Transmedia Vlog Adaptation
}

\author{
Les adaptations néo-victoriennes transmédiatiques en vlog : l'exemple de \\ Carmilla
}

Caroline Duvezin-Caubet

\begin{abstract}
I was anxious on discovering this paper, to reopen the correspondence commenced [...] so many years before, with a person so clever and careful [...]. Much to my regret, however, I found that she had died in the interval. She, probably, could have added little to the Narrative which she communicates in the following pages with, so far as I can pronounce, such conscientious particularity. (Le Fanu 242)
\end{abstract}

1 This is how an anonymous "editor" introduces Joseph Sheridan Le Fanu's Carmilla (1872), framing the novella as a found manuscript. However, over a century after its initial publication, the "clever and careful" narrator Laura did get to add to her story and re-open her conscientious and particular communication through new media: Youtube and the world-wide web. Carmilla: The Web Series (2014-2016), created by Jordan Hall and Ellen Simpson, was launched in the wake of the outstanding success garnered by Emmy-award-winning The Lizzie Bennet Diaries (2012-2013). In one hundred episodes ranging in length from 2 to 8 minutes, the series' creators Bernie Su and Hank Green managed to preserve the core of Jane Austen's classic Pride and Prejudice (1813) while radically modernizing it in terms both of focus and of medium. The goal of the Bennet sisters was redirected towards hunting for jobs rather than husbands and the cast of characters made to reflect the ethnic and sexual diversity of modern-day California. Meanwhile, the show relied on what Henry Jenkins calls "transmedia storytelling", "a process where integral elements of a fiction get dispersed systematically across 
multiple delivery channels for the purpose of creating a unified and coordinated entertainment experience" (Jenkins). The characters' Twitter, Facebook, Instagram and Tumblr accounts weaved their own narratives in conversation with the Youtube videos, narratives into which the viewers could and did participate. The formula was soon applied (by Green and Su's Pemberley Digital company and by other creative teams) to other Austen books, to Jane Eyre, Anne of Green Gables or Little Women, creating the genre of literary transmedia "vlog" adaptations. These nineteenth-century classics not only came with a built-in female fanbase and no copyright attached, but also coming-of-age stories perfect to be reinvented within the constraints of the video blog, or vlog, which performs intimacy for an audience of online strangers via a single, fixed webcam. The constraints spur on creativity while allowing for a small budget, and most of these neoVictorian adaptations fit comfortably within that frame.

Carmilla does not-both metaphorically and literally, as the small bedroom set of season 1 became more and more crowded with half a dozen actors, constantly running in and out of frame while trying to contain the supernatural kabbala taking place offscreen on the campus of Silas University. The series clearly owes as much to Joss Whedon's Buffy the Vampire Slayer (1997-2003) as to its official source material. Le Fanu's novella provides the basis for about half of the main cast, whether heroines and helpers (Laura Hollis, Carmilla Karnstein, Bertha Spieldorf/Betty, Mme Perrodon/Lola Perry, Mlle De la Fontaine/s. La Fontaine) or opponents (Matska/Mattie, the Dean, Baron Vordenburg), but only very loosely. Neither fidelity nor realism are really the issue here, but it makes one wonder why the creators chose a Gothic, intimate tale of deceit and seduction with a format which seems more suited for light, humorous drama and romance $-{ }^{1}$ and then build an epic, action-packed apocalypse plot (complete with evil goddesses, virgin sacrifices and giant mushrooms) around it.

However, this generic tension is precisely what makes the webseries so interesting: in this paper, we will put this revamped Carmilla (which plays with its media constraints while constantly bursting out of its Victorian corset) in conversation with its Gothic origin. Indeed, the Gothic genre and tradition is obsessed with limits and thresholds- ${ }^{2}$ those same thresholds which, according to folklore, a vampire cannot cross without invitation.

4 To that purpose, we will first study more closely how Carmilla's original story is staged within one episode and the tonal/generic shift which takes place in it. We will then consider the difference that a camera of her own can make to establish a female rather than a male gaze, before finally diving into the ideological core of the neo-Gothic adaptation: a narrative of queerness, femininity, and community.

\section{Tragedy, comedy and revelation: Staging Carmilla}

5 Literary vlog adaptations, whether they deal with vampires or not, generally try to adhere to an appearance of verisimilitude: in each episode, the chronicler turns on the webcam to recount what happened to her in the last few days, and the fact that she is frequently interrupted by other characters fortuitously giving new information or providing counterpoints in real time falls under suspension of disbelief. ${ }^{3}$ The epic battles and supernatural events happening over the course of the three seasons are not shown on screen (except some vampire super-strength and speed via special effects) but narrated retrospectively to the camera. Season 1 takes place in Laura and Carmilla's 
dorm room, season 2 in the living room and the bedroom of a house reserved for faculty lodgings which they have commandeered, and season 3 in a magic library where the heroines are trapped until the final battle. Storytelling is used to maintain the Aristotelian unity of space as well as of time, something which is illustrated in a metafictional way in episode 20 of season 1, "Sock Puppets and European History". Carmilla has been captured by Laura and her friends and she has to prove that she did not kill Laura's former roommate Betty. She starts to tell her origin story as a vampire, which begins with her being murdered at a ball in the late seventeenth century in Austria, but Laura interrupts her, protesting that she cannot tell such an exciting, dangerous story like a "boring history lesson", and runs out of the camera frame. After a jump-cut, Carmilla (still bound and wearing a garlic necklace) reappears framed behind a cardboard theater setting complete with red curtains, as well as candles in the foreground for atmospheric lighting. Laura is hiding below the frame, holding up sock puppets. The subsequent analepsis relies on theatrical double enunciation and fills in some gaps, such as the role of Carmilla's nameless "mother" who acts as a sort of vampire pimp in Le Fanu's story: here, she becomes the architect behind the disappearances of young girls and is revealed to be the Dean of Silas University at the very end of the episode. But it is also a good catalyst to reveal who Carmilla is behind her cynical persona; the scene creates a genuine bonding moment between the heroines as well as between the characters and the audience.

6 The tonal shift between comic and tragic is key. At the beginning, when Carmilla asks with blasé irony: "You don't think perhaps this makes light of my tragic backstory?", Laura answers good-humoredly "Oh get over yourself, come on!" ("Sock Puppets and European History" 00:00:50-00:00:54). The excess of emotions and secrets which comes with the Gothic lends itself very easily to ridicule, and the best way to deal with that in modern adaptations is to hang a lantern on it-or sock puppets. At first, Laura seems to have great fun staging Carmilla's murder like a vaudeville: "Oh, I die, I die! Cruel fate but to blast the blossom of my youth! [choking noises]" (00:01:09-00:01:16). She then gets caught up in reenacting the narrative with music and dialogue. When we get to the core of the story of Elle (which takes place in 1872), the sock puppets provide a sort of humorous barrier in the foreground while we can see Carmilla being actually moved by the memory in the middle ground. But as tragedy strikes, Laura can no longer keep up the pretense, and her head rises out of the frame she has designed, breaking the illusion. Towards the end of Carmilla's narration, after she concludes that her "price for the disobedience was to watch Elle be taken away to some [...] certain doom, and to be sealed away in a coffin of blood that [she] may waste away [her] long centuries in the dark" (00:04:20-00:04:35), five seconds of deafening silence follow. Filled with horror and pity, the moment rings all the more true because we are imagining it rather than seeing it. The theatrical tradition of off-stage events being recounted also echoes the Gothic tradition of embedded narratives. Heroines rarely see the true source of horror: it is whispered about, glimpsed in the shadows. This allows us to concentrate on their emotions and reactions, and this scene summons the "ghost" of Elle much more effectively than any special effect could.

7 Moreover, the show also uses "the Gothic lesson that only by confronting the ghosts of the past is progress possible" (Davison 211). Carmilla's last repetition of her seduction routine is what allows her to break the tragic cycle of deception, loss and guilt. Le Fanu's Laura is mirrored in Elle, the ingenue who was unable to accept Carmilla for 
what she was, namely a vampire and a lesbian. However, she is also the modern Laura, who can bring about a comic rather than a tragic resolution (i.e. a happy ending) without "making light" of centuries of suffering. The way the story is filmed is as integral to that transformation as the narrative being told-and this is where the overwhelmingly female cast and crew come into play.

\section{A camera of her own: A female gaze?}

8 In her 1975 essay "Visual Pleasure and Narrative Cinema", Laura Mulvey coined the term "male gaze" to describe the way in which women are objectified by the cinematic genre, framed as passive objects of desire for the camera and the viewer who becomes a voyeur (837). Vlogs are supposed to be shot via webcam, a tool not generally associated with protecting one's privacy. But since the protagonist/diarist of each literary vlog adaptation is the one posting the videos, she has complete creative control. Within the fictional contract of the medium, she decides whom she lets into the frame, and when to cut the camera to restore her privacy. Meta-fictionality is part of the game: we know that the characters are projecting personas, and a lot of the pleasure comes from catching details, hidden smiles, stolen looks which show what they are "really" thinking. This is easily done in The Lizzie Bennet Diaries, which is brightly lit and filmed mainly in medium close-ups, with generally no more than two characters on screen. Carmilla: The Web Series, however, uses significantly less lighting on set (probably because some characters are vampires), is filmed mainly in medium shots or threequarters shots, and typically features several interactions happening simultaneously in the background and the middle ground. The screen gets very busy and there is a single sound source. As a result, the writers and directors often rely on theatrical rather than cinematic techniques to show the characters' thoughts and emotions: they end up telling the camera how they feel, with a lot of dramatic pauses and exaggerated anger, excitement or dejection. The subtlety of the acting suffers from the set-up. However, the static camera gives the female characters not only control of their image and their narratives, but a way to change the world.

Gothic novels are often focused on the relationship between the heroine and the haunted castle or mansion in which she is trapped: the things she discovers there by candlelight are intrinsically linked to her repressed fears and desires. Le Fanu's Laura is a very passive character whose father and doctor withhold vital information from (using her nerves as an excuse), not only about Carmilla's true nature or intentions but even about Laura's own physical state. This proprietary attitude towards female bodies and voices is also (though of course not exclusively) strikingly Victorian, and it is interesting to note the continuity between the kinds of patriarchal silencing/ gaslighting ${ }^{4}$ which Le Fanu's Laura and Laura in the webseries (who is anything but passive) have to face. However, the modern Laura is also a journalism major: she does not just discover things, she shouts the truth from the rooftops-or the internet. She starts her vlog as an assignment for her 102 Journalism class, but uses it to raise awareness over the suspicious disappearance of her roommate. Through seasons 1 and 2 , she tries to inform and protect the students of Silas University despite the policy of censorship and fake news enforced by the Dean. Season 2 begins with the murder of the whole student newspaper crew which Laura attempts to solve while stepping in for them. In season 3, the spatial dislocation of the Resistance is mirrored in terms of 
medium: Mel and Kirsch, who are hiding in the underground tunnels, set up their own podcast, "Transmissions from the Pit", while Laura's library vlogs can only occasionally get through the university firewall. When they manage to communicate, a smaller screen appears in the left bottom corner; it also occasionally contains the flickering avatar of JP, their resident ghost/tech genius, or lines of code from his attempts to break the firewall. Communication and investigation techniques ${ }^{5}$ are thus represented graphically on the surface of the screen, creating the illusion of progress without actually changing settings: the camera only becomes handheld at the end of season 2 and season 3, during the final fights which include different angles and lighting.

The show uses even more low-tech tricks when Laura modulates their living space to represent the limits between public and private: as anchor of the Silas News Network, she is seated in front of a simple grey curtain masking the living room, repeatedly pulled back as Perry passes her more and more ridiculous news update ("SNN"); when she cannot stand Carmilla's messiness on the top floor anymore after one of their break-ups, she divides the bedroom dramatically with strands of yellow police tape ("Old Habits" 00:01:07-00:01:40). It's possible to read this in conversation with the Victorian theory of separate gender spheres (epitomized by Coventry Patmore's "The Angel in the House"), but the echoes with twentieth-century feminist ideas are much more striking. Virginia Woolf wrote that "a woman must have money and a room of her own if she is to write fiction" (4). Within the fictional world of Carmilla: The Web Series, Laura uses a camera (the Latin word for "room") of her own to shed light on the truth about the imminent apocalypse (thus revealing a revelation, etymologically speaking). Nonetheless, despite the increasingly political tone of the show, the female reclaiming of space and framing never loses sight of its most important target: the relationship between Laura and Carmilla. At several points in season 3, the heroines start making out enthusiastically in the foreground; the image then cuts for four seconds to a picture of a control room with striped "technical difficulties" TV screens (but in the rainbow colors of the LGBTQ+ flag), overlaid with another picture of a laughing Laura and Carmilla and the message "Oops, we did it again! We'll be right back!" while elevator music plays, before coming back to a very disheveled but happy Laura ("Coping Strategies" 00:10:40-00:10:52). Editorial control makes this a humorous, endearing moment which Laura chooses to share with her viewers rather than a fetishization of lesbian desire. In a similar manner, Laura and Carmilla cuddling in the middle ground always appears intimate rather than intrusive: the static camera liberates the audience from voyeurism in a simple yet revolutionary way, instead making them part of the Resistance where the private is political.

\section{Creampuffs Unite! Queerness, femininity and community}

11 Monsters in general and vampires in particular have always been associated with expressions of sexuality and gender which differ from the norm. Bram Stoker's Dracula (1897), with the predatory brides and the Count who "feeds" Mina from a bloody wound on his chest to transform her, is a famous example. Harry Benshoff argues in Monsters in the Closet that "the figure of the monster throughout the history of the Englishlanguage horror film can in some way be understood as a metaphoric construct standing in for the figure of the homosexual" (4). However, this kind of subtext, 
whether in film or in literature, does not necessarily mean that the representation is not homophobic. In Le Fanu's story, Laura's feelings towards Carmilla are at best ambivalent: "I experienced a strange tumultuous excitement that was pleasurable, mingled with a vague sense of fear and disgust [...]. I was conscious of a love growing into adoration, and also of abhorrence" (264). Carmilla's desire for Laura's blood and Laura's body/heart is presented as wrong, predatory, and perverting. Caught between fetishization and moral panic, lesbian vampires have not fared very well in cinema, as can be seen in Daughters of Darkness and especially Vampyros Lesbos (both 1971). Moreover, despite the contemporary progress in positive, nuanced representation of queer characters, they still run the risk of being killed off at a drop of the hat. This is called "bury your gays" or "the dead lesbian trope": a queer love interest dies heroically just after having professed or consummated their love, as if the narrative were punishing them for their sexuality. One of the best-known examples in television is Tara Maclay, Willow's girlfriend in seasons 4 to 6 of Buffy the Vampire Slayer, who was killed off in "Seeing Red" despite the show's progressive reputation. More recently, queer fans of The 100 voiced their outrage when Clarke's love interest Lexa was killed off in March 2016, setting off a wave of activism which led to funds collected for The Trevor Project (suicide prevention for LBTQ+ youths) and several showrunners signing "The Lexa Pledge", thus promising to do better by LGBTQ+ characters in the future. ${ }^{6}$ The dead lesbian trope is subverted twice in Carmilla: once when she sacrifices herself at the end of season 1 (which doesn't take because she is a vampire), and then when Laura sacrifices herself at the end of season 3, prompting an ancient goddess to comment: "There are no miracles without sacrifices [...]. She did the impossible. This girl changed the story of the world" ("Post Apocalypse" 00:00:38-00:00:52). Carmilla, however, refuses to accept that; she tricks Death into bringing Laura back, and shouts to the Universe: "No! No! This is not how her story ends!" (00:05:30-00:05:36) The proclamation also comes true on a meta-fictional level: this is a transmedia adaptation, which will never really end and does not run linearly.

In addition to the social media tools used by The Lizzie Bennet Diaries, Carmilla: The Web Series also relies on newer platforms like Wattpad with the "Silas Confidential" story, which follows the adventure of student Mary Ringwold in the timeframe in season 1 . The devil is in the details: on Twitter, @Laura2TheLetter follows the official accounts of the fiction podcast Welcome to Night Vale and the high school detective TV show Veronica Mars, which are both clear inspirations for the webseries. Meanwhile, @HeyCarmilla (geolocalized at "None of your business") follows no one except Laura and tweets snarky comments, but also, two days before the penultimate episode of season 1 where she sacrifices herself: "I suppose, if you have to be doomed, there are worse things than love to be doomed for" (24/11/2014). The 140-character limit is one of the tight frames which spurs on nuance and creativity: a tweet from @SilasUniversity, which reads "Here at Silas, students are encouraged to embrace the core Corvae virtues of stoicism, silence, and sixteen tons of pit excavation daily", is later quote-tweeted by JP Armitage (@SilasBookWorm) who comments above: "4759RJ:\&*O\&S( < < <I-I-If;guess yourrr neW recruiting m-m-m-OTto iiiis “C-can you D-D-Dig it it??"'”"'\$Tqac8izuio> >S\#@@ [sic]” $(01 / 10 / 2016)$. The distortion of the typography can be linked to his haunting and/or to the effect of the firewall, but it also seems to pick apart the propaganda-like use of alliterations and ternary rhythms of the original message, showing the moral corruption which lies beneath the pithy surface. Appropriately enough for the account of a ghost, @SilasBookWorm is now no longer in service. 
13 What seems to set Carmilla: The Web Series apart from other literary transmedia vlog adaptations is the sheer amount of content which exists around the show: interviews, games, Q\&As... including a quiz competition on period protection between secondary characters Danny and Kirsch to really hammer home that the show is sponsored by $\mathrm{U}$ by Kotex ("FIGHT-O!"). There are now more hours of content available around the show than all the episodes put together-and they are not really "extras" as such: the interactivity, the connections to the fan community, are the heart of the show's success and spirit. ${ }^{7}$ Youtuber Elisa Hansen has pointed out that the show took the fanbase's criticism to heart when it came to racial diversity: secondary characters Will, Mel and Mattie, ${ }^{8}$ all played by actors of color, entered the cast after season 1 . In her video essay, Hansen also remarks on the misogyny against traditional femininity which Carmilla expresses by calling Laura dismissively "cupcake" or "creampuff", something which the show implicitly condones in the way it frames Carmilla (00:18:57-00:19:04). The fanbase, however, reclaimed the patronizing nicknames by christening themselves "Creampuffs" who are "soft and gooey inside and damn proud of it" (00:19:28-00:19:30). Laura and Perry do not fight (one training montage has the former brandishing a spatula): they cook, clean, research and take care of their loved ones, which doesn't make them any less heroic and willing to stand up for what is right. This is a feminist show, which primarily targets straight cisgender women, queer cisgender women and gender non-conforming individuals: the data collected by Stephanie Skinner for her 2016 anthropology thesis on Carmilla: The Web Series showed that the last group was in the minority (24.3\%) compared to cisgender men and women (75\%), but that only $3 \%$ of the sample identified as heterosexual (20). Representation matters, both in front and behind the camera: we know that producer Steph Ouaknine is queer herself, that Natasha Negovanlis (Carmilla) is a lesbian, that Elise Bauman (Laura) is bisexual, and that Kaitlyn Alexander, who plays the non-binary mad scientist La Fontaine, credits the role for helping them explore their gender identity and discover that they are, indeed, non-binary (Alexander 00:01:30-00:02:00). When Creampuffs were asked to send in short videos to explain what Carmilla: The Web Series meant to them, most of the respondents also identified themselves as queer, and one of them, @muscleskrenzer, said: "You have shown that our stories matter. We exist, and we shouldn't have to apologize for that" ("Thankful For You" 00:01:41-00:01:48).

In Limits of Horror, Fred Botting warns that if new Gothic modes "collude with the norms they once negatively defined", then "[d]ifference and otherness, too, are absorbed in the serial circulations of the same, a flat plane of indifference, the monstrosity of norms" (Botting 2008, 10). However, there can also be subversion in erasing difference: in Carmilla: The Web Series, the ethical issues linked to Carmilla's vampire nature have nothing to do with her sexuality, and the notion of having to come out as a lesbian does not even occur in the series until Laura's father makes an appearance in season 3. Carmilla, Laura, Danny or Mel's homosexuality is a non-issue within the world of the show, although La Fontaine's non-binary gender identity is hard to accept for their childhood friend Perry. In Post-Millennial Gothic, Catherine Spooner calls for a rehabilitation of romance and humor, which are just as much part of the genre as the tradition of terror, and asserts "the presence and cultural significance of a counternarrative of Gothic texts that combine conventional markers of the Gothic with a mood of pleasure, lightness, and celebration" (Spooner 537-538). Her "happy gothic" is definitely relevant for Carmilla: The Web-Series, as is the notion that "celebration [...] can itself be a political choice" (414). Both the happy end and the often ridiculous action 
sequences (as recounted on-screen) act as a balm for the Victorian legacy of traumatic and tragic queer representation, which often falls short even in neo-Victorian fiction: Marie-Luise Kohlke and Christian Gutleben have rightly pointed out that in A.S. Byatt's Possession: A Romance (1990) "[ $t$ ]he failure of non-orthodox sexual experiences and the narrative resolution through heterosexual romance betray the novel's conservative structure and its apparent advocacy of the traditional family unit" (Kohlke and Gutleben 9). Sarah Waters' novels, of course, are the exception to that rule, as they reconstruct "a continuum of same-sex desire" (Joyce 154). Used as bait in the Dean's plan, Carmilla's desire submits her to guilt and suffering for centuries, until her romance with Laura breaks the tragic cycle in the twenty-first century. The show is very much about found families, and the Creampuffs would probably be delighted to reclaim the "candygothic" subgenre which Botting bemoans (Botting 2001, 134).

In addition to its three main seasons, the show counts a twelve-episode season zero where Carmilla investigates the disappearance of menstrual cycles, a feature film which was released online on October 26 2017, and a novel adaptation of the series penned by Kim Turrisi which was released in May 2019 by Kids Can Press. The movie, which is beautifully shot and paced and features an Alice in Wonderland-themed opening, has Carmilla literally face off with the ghosts of her past in the form of Elle, as the heroines and their friends are trapped in a haunted castle, with obligatory period dresses and suits. As such, the film is specifically neo-Victorian in its aesthetics while the main series, despite the fact that it modernizes and interrogates a Victorian classic, remains more generally neo-Gothic in its costumes and setting (which might be a budget issue as much as a creative choice). It will be interesting to consider the original novella in conversation with the webseries, the movie and the 2019 novelization in terms of intermediation and transmediation-however, these official sequels are not necessarily more legitimate than the over 6,000 fanfictions posted to Archive of Our Own. The story goes ever on and on, out of the closet where it began, out of the haunted castle and into the light.

\section{BIBLIOGRAPHY}

Alexander, Kaitlyn. "We Wrapped Carmilla S3 (And I have feelings about it)". Realisticallysaying. 14 August 2016. Youtube. www.youtube.com/watch?v=aTDKeqwMiPY\&feature=youtu.be\&t=90, last accessed 14 November 2018.

Botting, Fred. “Candygothic”. The Gothic. Fred Botting (ed.). Cambridge: D.S. Brewer, 2001, 133-151.

Botting, Fred. Limits of Horror: Technology, Bodies, Gothic. Manchester: Manchester UP, 2008.

"Bury Your Gays". TV Tropes. https://tvtropes.org/pmwiki/pmwiki.php/Main/BuryYourGays, last accessed 13 November 2018.

“Coping Strategies". Carmilla: The Web Series, created by Jordan Hall and Ellen Simpson, season 3, episode 19, Kinda TV, 29 September 2016. Youtube. www.youtube.com/watch? 
v=NB4C4viqZQo\&list=PLbvYWjKFvS5p8JB-IkWjmr3IKdDuSYi1d\&index=19, last accessed 26 January 2018.

Davison, Carol Margaret. "Monstrous Regiments of Women and Brides of Frankenstein: Gendered Body Politics in Scottish Female Gothic Fiction". The Female Gothic: New Directions. Diana Wallace and Andrew Smith (eds.). Basingstoke: Palgrave Macmillan, 2009, 196-214.

Delamotte, Eugenia. Perils of the Night: A Feminist Study of Nineteenth-Century Gothic. Oxford: Oxford UP, 1990.

"FIGHT-O! The Greatest Underwarrior", Kinda TV, 16 October 2014. Youtube. www.youtube.com/ watch?v=IieFtRgOTVk, last accessed 14 November 2018.

Guillaud, Lauric and Jean-Pierre Picot. Les Détectives de l'étrange : domaine anglo-saxon. Paris :

Éditions Le Manuscrit, 2007.

Hansen, Elisa (Maven of the Eventide). "Vampire Reviews: Carmilla (webseries)". 23 December 2016. Youtube. www.youtube.com/watch?v=OPGwE1CZBQE, last accessed 2 January 2017.

Hunter, Aaron. "Summer Web Series: lonelygirl115". The Catcher in the Reel: Media Matters in Review. 24 August 2014. https://catcherinthereel.wordpress.com/2014/08/24/summer-webseries-series-lonelygirl115/, last accessed 21 June 2017.

Jenkins, Henry. Textual Poachers: Television Fans and Participatory Culture (1992). New York and London: Routledge, 2013.

Jenkins, Henry. “Transmedia 202: Further Reflections”. Confessions of an Aca-Fan: The Official Weblog of Henry Jenkins. 1 August 2011. http://henryjenkins.org/blog/2011/08/

defining_transmedia_further_re.html, last accessed 19 May 2017.

Joyce, Simon. The Victorians in the Rearview Mirror. Athens (Ohio): Ohio UP, 2007.

Kohlke, Marie-Luise and Christian Gutleben. “Introducing Neo-Victorian Family Matters”. NeoVictorian Families: Gender, Sexual and Cultural Politics. Marie-Luise Kohlke and Christian Gutleben (eds.). Amsterdam: Rodopi, 2011, 1-42.

Kohlke, Marie-Luise and Christian Gutleben. "The (Mis)Shapes of Neo-Victorian Gothic: Continuations, Adaptations, Transformations". Neo-Victorian Gothic: Horror, Violence and Degeneration in the Re-Imagined Nineteenth Century. Marie-Luise Kohlke and Christian Gutleben (eds.). Amsterdam: Rodopi, 2013, 1-48.

Le Fanu, Joseph Sheridan. Carmilla (1872). In a Glass Darkly. Robert Tracy (ed.). Oxford: Oxford UP, 1993.

"Old Habits". Carmilla: The Web Series, created by Jordan Hall and Ellen Simpson, season 2, episode 16, Kinda TV, 23 July 2015. Youtube. www.youtube.com/watch?v=C4orFR7-

uVs\&list=PLbvYWjKFvS5q3y3BO-qkmo7FQ8jwlwj5v\&index=16, last accessed 20 January 2018.

“Thirteen". The 100, created by Jason Rothenberg, performance by Eliza Taylor and Alicia Debnam-Carey, season 3, episode 7, The CW, 3 March 2016.

"Post Apocalypse". Carmilla: The Web Series, created by Jordan Hall and Ellen Simpson, season 3, episode 36, Kinda TV, 13 October 2016. Youtube. www.youtube.com/watch?v=_eidHvz0xk\&index=36\&list=PLbvYWjKFvS5p8JB-IkWjmr3IKdDuSYi1d, last accessed 2 February 2018.

"Seeing Red". Buffy the Vampire Slayer, created by Joss Whedon, performance by Sarah Michelle Gellar, Amber Benson and Alyson Hannigan, season 6, episode 19, WB Television Network, 7 May 2002. 
"SNN". Carmilla: The Web Series, created by Jordan Hall and Ellen Simpson, season 2, episode 3, Kinda TV, 9 June 2015. Youtube. www.youtube.com/watch? v=znoJZM7kwWU\&list=PLbvYWjKFvS5q3y3BO-qkmo7FQ8jwlwj5v\&index=3, last accessed 19 January 2018.

"Sock Puppets and European History". Carmilla: The Web Series, created by Jordan Hall and Ellen Simpson, season 1, episode 20, Kinda TV, 7 October 2014. Youtube. www.youtube.com/watch? $\mathrm{v}=\mathrm{UGaSQQmCtg} 4$ \&index=20\&list=PLbvYWjKFvS5rX2yv-k5AJ8oxPoZ9zHcpe, last accessed 15 January 2018.

Stoker, Bram. Dracula (1897). London: Penguin Books, 2003.

The Lizzie Bennet Diaries, created by Hank Green and Bernie Su, Pemberley Digital. 2012-2013. Youtube. www.youtube.com/watch?v=KisuGP2lcPs\&list=PL_ePOdU-b3xcDyyzeR5NjxeLEElsqYzn, last ccessed 14 July 2017.

Mulvey, Laura. "Visual Pleasure and Narrative Cinema" (1975). Film Theory and Criticism: Introductory Readings. Leo Braudy and Marshall Cohen (eds.). Oxford: Oxford UP, 1999, 833-844.

Nakagawa, Chiho. "Safe Sex with Defanged Vampires: New Vampire Heroes in Twilight and the Southern Vampire Mysteries". Journal of Popular Romance Studies 2:1 (2011). http://jprstudies.org/ 2011/10/\%E2\%80\%9Csafe-sex-with-defanged-vampires-new-vampire-heroes-in-twilight-and-thesouthern-vampire-mysteries\%E2\%80\%9D-by-chiho-nakagawa/, last accessed 14 November 2018.

Spooner, Catherine. Post-Millenial Gothic: Comedy, Romance and the Rise of the Happy Gothic. London: Bloomsbury, 2017.

Skinner, Stephanie. "Queer Subjectivity, Transmedia, and Embodiment in the Carmilla Fandom". BA Thesis. Georgia State University, 2016. https://scholarworks.gsu.edu/anthro_hontheses/13/, last accessed 12 February 2018.

“Thankful For You". U by Kotex, 24 November 2015. Youtube. www.youtube.com/watch? v=teOG7FKYwbo, last accessed 3 March 2018.

Woolf, Virginia. “A Room of One's Own” (1929). Feedbooks, http://seas3.elte.hu/coursematerial/ PikliNatalia/Virginia_Woolf_-_A_Room_of_Ones_Own.pdf, last accessed 13 November 2018.

\section{NOTES}

1. The modern adaptation Frankenstein, M.D. (2014, produced by Pemberley Digital and PBS Studios) used a Youtube channel in which medical students Victoria Frankenstein and Iggy De Lacey present advances in modern science as its premise. For the first 14 episodes, the tone is light and humorous, with no storyline to speak of other than Victoria's prickly ambition, her friends' love life, and her sibling-like quarrels with Iggy. In episode 15, she uses those same advances in modern science to bring her friend and cameraman Robert Walton back to life. After that, the atmosphere shifts dramatically to a police procedural/horror set-up as they try to track the creature's movement and then to outright tragedy as childhood friend Eli Lavenza is killed after he and Victoria have declared their feelings for each other. At this point, the series ends abruptly, and it's tempting to see it as a failed experiment (not unlike the creature itself) in maintaining the in-world premise for the videos. Victoria is not the kind of character who would keep broadcasting her feelings to strangers after a personal tragedy - Laura, as we will see in the second part of this article, is another matter. 
2. For Eugenia Delamotte, the Female Gothic is concerned with the "boundaries of self" which are linked to the negotiations of thresholds: fending off an intruder or struggling to escape from an underground cellar symbolize those anxieties (19).

3. It is very easy to 'forget' the framing device and play along: many Youtube commenters address the characters like real people, empathizing with their feelings in the moment rather than relying on their knowledge of the source material (those who do make meta-commentaries generally do not address the characters). The medium seems to invite realism, despite the fact that it started playing with fictional possibilities almost as soon as Youtube was created in 2006: in his blog series recounting the history of the vlog, Aaron Hunter insists on the shock and surprise of lonelygirl115's audience when it was revealed that she was actually an actress and that her videos were scripted. No such deception took place for The Lizzie Bennet Diaries or Carmilla; but strangers casually perusing the characters' social media profiles might misunderstand anyway (at least one man has attempted to flirt with Jane Bennet on LookBook).

4. To gaslight someone means to manipulate them psychologically into doubting their memory, interpretation or even sanity, in particular about forms of abuse which the "gaslighter" might have subjected them to. Though the term originated in the 1940s, the process is much older.

5. The Gothic tradition acts as forefather both for realist detective fiction and for the speculative genres of fantasy, science fiction and horror, all of which start to emerge in the nineteenth century. Edgar Allan Poe's work, which comprises fantastic stories like "The Tell-Tale Heart" (1843) but also "Murders in the Rue Morgue" (1841), one of the first detective stories, is a good example of the Gothic tension between emotion and reason. More recently, the traditions have merged again with the advent of urban fantasy, where crimes involving werewolves, ghosts and magic can be solved with reason within the rules of the world. Laura could definitely be considered as one of these détectives de l'étrange, these uncanny detectives analyzed in the 1999 Cerisy conference organized by Lauric Guillaud and Jean-Pierre Picot.

6. For more details, see the website were everything was organized once the hashtag \#LGBTfansdeservedbetter started trending (and where a lot of tweets and articles chronicle the movement), http://wedeservedbetter.com/.

7. Note that whereas following along in real-time encourages viewers to seek out supplementary material in between Youtube video uploads, discovering and watching the series later (as was the case for this article) makes the transmedia aspect much more theoretical: social media posts have been buried under newer contents, and the need to fill in the blanks by clicking away from the main series is much less present. Le Fanu's Carmilla was originally serialized (in the literary magazine The Dark Blue), like many other Victorian classics. It seems likely that the chosen format of Carmilla: The Web Series is simply following The Lizzie Bennet Diaries rather than making a specific comment on the serialization of novels, but this does not preclude some transhistorical comparisons.

8. Matska, a racist caricature, who is barely glimpsed in Le Fanu's novella, is here reclaimed as a complex and powerful black woman.

\section{ABSTRACTS}

Several transmedia literary adaptations of nineteenth-century classics followed in the wake of the success of The Lizzie Bennet Diaries (created by Bernie Su and Hank Green and aired in 2012-2013). Despite the fact that vampires do not exactly fit into the verisimilitude of the single- 
frame vlog filming style, Carmilla (2014-2016) stands out as one of the most stylistically and ideologically progressive. Freely adapted from Joseph Sheridan Le Fanu's 1872 novella, the work of creators Jordan Hall and Ellen Simpson subverts the clichéd association of vampirism and lesbianism to free the female characters from the male gaze. Feminism has been a given in the transmedia literary adaptation since $L B D$, and some shows have taken the stories they adapt out of their heteronormative frame, but no other centers queer experience as radically as Carmillaboth behind and in front of the camera. Queer sexualities and gender identities are front-andcenter, and appear perfectly natural against the background of the Buffy-inspired supernatural kabbala which plays out at Silas University. Fun, engaging and sometimes camp, the neo-Gothic webseries has garnered an extensive fandom and a continuation in movie form. As such, it embodies the way these new, self-reflexive possibilities of transmedia storytelling build on the audience's involvement to promote issues of female (and queer) agency which reflect upon and playfully challenge social and aesthetic limits.

Plusieurs adaptations transmédiatiques de classiques du XIX ${ }^{\mathrm{e}}$ siècle ont cherché à imiter le succès de The Lizzie Bennet Diaries (2012-2013). Malgré l'obstacle que les vampires représentent pour un style de vlog pseudo-réaliste avec caméra fixe, Carmilla (2014-2026) sort du lot, se distinguant comme l'une des adaptations les plus progressives sur le plan stylistique et idéologique. Librement adaptée du court roman de 1872 de Joseph Sheridan Le Fanu, l'œuvre des créatrices Jordan Hall et Ellen Simpson réinvente le lien entre vampirisme et lesbianisme pour libérer les personnages féminins du voyeurisme masculin. Quasiment toutes les adaptations depuis LBD sont féministes, et certaines adaptent leurs histoires originelles hors du cadre hétéronormatif, mais aucune ne se concentre sur l'expérience LGBTQ+ autant que Carmilla, que ce soit pour le produit fini ou pour le processus de création. Les sexualités et les identités de genre queer sont placées au premier plan, parfaitement naturelles sur le fond de cabbale surnaturelle à la Buffy qui chamboule Silas University. Drôle, prenante et parfois ironique, cette web-série néo-gothique rassemble de nombreuses fans qui ont porté une suite sur le grand écran. C'est un exemple-type de la façon dont ces nouvelles formes réfléchies de narration transmédiatique utilisent l'interactivité pour mettre en lumière des questions d'agentivité féminines et queer, critiquant de façon ludique nos limites sociales et esthétiques.

\section{INDEX}

Keywords: vampire, neo-Gothic, transmedia, queer, feminism, vlog, agency, humor, limit oeuvrecitee Buffy, Carmilla, Lizzie Bennet Diaries (The)

Mots-clés: vampire, néo-gothique, transmédiatique, LGBTQ+, féminisme, vlog, agentivité, humour, limite

\section{AUTHORS}

\section{CAROLINE DUVEZIN-CAUBET}

Caroline Duvezin-Caubet passed the agrégation in 2013 and successfully defended her PhD, supervised by Christian Gutleben and entitled "Steam Dragons: Towards a Poetics of Contemporary Neo-Victorian Fantasy" in September 2017. She has published articles on contemporary speculative fiction writers like Terry Pratchett, Neil Gaiman, Seanan McGuire and China Miéville, an entry for the Dictionnaire de la fantasy and an article on postcolonial steampunk for the publication of the first Imaginales colloquium on "Fantasy \& History". She is on the 
reading committee of the bilingual journal Fantasy Arts and Studies and in charge of the Twitter account for the CERLI, the Center of Studies and Research on Speculative Fiction. 